\title{
Ontogeny of central serotonergic neurons in the directly developing frog, Eleutherodactylus coqui
}

Accepted: 21 July 2005 / Published online: 7 September 2005

(C) Springer-Verlag 2005

\begin{abstract}
Embryonic development of the central serotonergic neurons in the directly developing frog, Eleutherodactylus coqui, was determined by using immunocytochemistry. The majority of anuran amphibians (frogs) possess a larval stage (tadpole) that undergoes metamorphosis, a dramatic post-embryonic event, whereby the tadpole transforms into the adult phenotype. Directly developing frogs have evolved a derived lifehistory mode where the tadpole stage has been deleted and embryos develop directly into the adult bauplan. Embryonic development in E. coqui is classified into 15 stages (TS $1-15 ; 1=$ oviposition $/ 15=$ hatching). Serotonergic immunoreactivity was initially detected at TS 6 in the raphe nuclei in the developing rhombencephalon. At TS 7, immunopositive perikarya were observed in the paraventricular organ in the hypothalamus and reticular nuclei in the hindbrain. Development of the serotonergic system was steady and gradual during midembryogenesis. However, starting at TS 13 there was a
\end{abstract}

\section{G. R. Ten Eyck}

Department of Psychology, Biopsychology Area,

The University of Michigan, Ann Arbor, MI, 48109-1109 USA

W. J. Jermakowicz III

Neuroscience Graduate Program, Vanderbilt Brain Institute, Vanderbilt University Medical Center,

Nashville, TN, 37240 USA

\section{A. F. Chinn}

Department of Biology, The University of South Dakota, Vermillion, SD, 57069 USA

\section{H. Summers}

Department of Biology and Neuroscience Group, Division of Basic Biomedical Sciences, School of Medicine,

The University of South Dakota, Vermillion, SD, 57069 USA

G. R. Ten Eyck $(\varangle)$

Department of Biological Sciences, Idaho State University, Pocatello, ID, 83209-8007 USA

E-mail: tenegary@isu.edu

Tel.: + 1-15208-2824410

Fax: $+1-15208-2824570$ substantial increase in the number of serotonergic neurons in the paraventricular, raphe, and reticular nuclei, a large increase in the number of varicose fibers, and a differentiation of the reticular nuclei in the hindbrain. Consequentially, E. coqui displayed a well-developed central serotonergic system prior to hatching (TS 15). In comparison, the serotonergic system in metamorphic frogs typically starts to develop earlier but the surge of development that transpires in this system occurs postembryonically, during metamorphosis, and not in the latter stages of embryogenesis, as it does in E. coqui. Overall, the serotonergic development in E. coqui is similar to the other vertebrates.

Keywords 5-Hydroxytryptamine - Development · Immunocytochemistry $\cdot$ Amphibian ·

Direct development

\section{Introduction}

Vertebrates have two principal groups of hindbrain serotonergic nuclei, the superior or B4-B9 group and the inferior or B1-B3 group (Dahlstrom and Fuxe 1964; Lidov and Molliver 1982; Wallace and Lauder 1983; Ekström and van Veen 1984; Parent et al. 1984; Wallace 1985; van Mier et al. 1986; Jacobs and Azmita 1992). All non-mammalian vertebrates also have serotonergic cells present in the diencephalon during embryonic development and as adults (Sano et al. 1983; Ekström and van Veen 1984; Ueda et al. 1984; Parent et al. 1984; Wallace 1985; van Mier et al. 1986). Diencephalic serotonergic cells are also present in adult mammals under conditions that elevate endogenous serotonin levels (Frankfurt et al. 1981; Lowry et al. 2003). In general, serotonergic development occurs early in vertebrates. Furthermore, the neurotransmitter serotonin has also been shown to act as a regulator of early embryogenesis and morphogenesis (Buznikov et al. 2001). 
Studies on the development of central serotonergic (5-HT) systems have included several vertebrate lineages including mammals (Lidov and Molliver 1982; Wallace and Lauder 1983; Ballion et al. 2002), birds (Wallace 1985; Sako et al. 1986; Okado et al. 1992), amphibians (Terlou et al. 1972; van Mier et al. 1986; Clairambault et al. 1994; Woolston et al. 1994), and fish (Ekstrom et al. 1985; Bolliet and Ali 1992; Bolliet et al. 1994; McLean and Fetcho 2004). Investigations on anuran amphibians have focused on frogs that are tadpoles during larval maturation and undergo metamorphosis (Terlou et al. 1972; van Mier et al. 1986; Roberts 1988; Woolston et al. 1994; Takeda 1997). Serotonergic ontogeny was examined in the African clawed-frog, Xenopus laevis, using immunocytochemistry (van Mier et al. 1986). Initial immunostained neurons appeared early in development, stage NF 25 (Nieuwkoop and Faber 1956), in the rostral part of the brain stem, and descending serotonergic axons reached the level of the anus prior to the time of hatching, NF 35/36. In the neobatrachian frog, Rana temporaria, the ventrolateral spinal cord is innervated by serotonergic cells of the raphe nuclei around the time of hatching, G 22 (Gosner 1960; stage 22) (Woolston et al. 1994). These investigators determined that the serotonergic system is established and functional at the time of hatching, and that it modulates swimming activity in the newly hatched tadpoles. In another study by using high performance liquid chromatography (HPLC), levels of biogenic amines were measured in the metamorphic frogs Bufo bufo and Rana nigromaculata. Levels of amines, including serotonin, were found to gradually increase through development but serotonin levels rose substantially during the climax of metamorphosis (Takeda 1997).

In frogs it appears that the serotonergic system is essential for at least some of their major life history events (e.g., hatching, metamorphosis) and frogs have certainly evolved a number of various and fascinating life history modes (Pough et al. 1998; Zug 1993; Duellman and Trueb 1986). Although there are many variations in life history, most frogs undergo metamorphosis, which results in dramatic modifications in virtually all aspects of their biology. However, some species of anurans have evolved a mode of development, whereby the free swimming tadpole stage is absent and the embryos directly develop into neonate frogs. In most vertebrates direct development is the typical mode, yet in anurans, metamorphosis remains the most pervasive mode of development. Research on metamorphosis has been widely studied for many years (Gilbert et al. 1996), whereas investigations on directly developing frogs have been relatively recent and most have utilized the frog, Eleutherodactylus coqui.

The Puerto Rican Coquí frog, E. coqui, is a directly developing anuran that has no aquatic tadpole stage and hatches directly as a terrestrial anuran. This frog exhibits many developmental modifications from the metamorphic anuran pattern including: repatterned skull development (Hanken et al. 1992), modified operculcum development and ontogenetic reorganization (Callery and Elinson 2000b), absence of the larval olfactory organs (Jermakowicz et al. 2004), early thyroid gland development (Jennings and Hanken 1998), and a $\mathrm{T}_{3^{-}}$ dependent developmental period, similar to what occurs during metamorphosis (Callery and Elinson 2000a; for reviews see Hanken 1999; Callery et al. 2001; Elinson 2001).

Several studies have focused on the developmental neurobiology of E. coqui. Many ancestral (larval) characters during peripheral nerve development have been omitted and the onset of limb and trunk innervation occurs in the early embryonic stages (Schlosser and Roth 1997b). The spinal cord development exhibits an accelerated ontogeny during embryogenesis, relative to other parts of the central nervous system, and displays rapid growth, high levels of cell proliferation and neurogenesis, and early formation of lateral motor columns (Schlosser 2003). These events are probably related to the precocious development of limbs in E. coqui, which are a mosaic of apparently conserved and novel features (Hanken et al. 2001; Schlosser 2003). Further developmental modifications in the nervous system of $E$. coqui include rapid retinal development, occurring without recapitulating the larval developmental pattern expressed in metamorphic taxa (Schlosser and Roth 1997a) and the loss of the lateral line system, due to the lack of ectodermal competence to form lateral line placodes in response to the inductive signals (Schlosser et al. 1999).

Many characteristics, neural and non-neuronal, have been eliminated or altered during the evolution of directly developing frogs. The objective of this study is to determine the ontogeny of the central serotonergic neurons in the directly developing frog, E. coqui, and to compare this ontogenetic pattern with metamorphic frogs and other vertebrates. This study utilized immunocytochemistry to ascertain the temporal and spatial patterns of serotonergic development in the brain.

\section{Materials and methods}

\section{Animals}

Embryos of E. coqui were obtained from spontaneous mating between wild-caught adults from Puerto Rico and maintained as a laboratory breeding colony in the Department of Psychology at the University of Michigan. Animals were kept on a 12:12 h. photoperiod, fed live crickets (dusted with vitamin and mineral powder) three times a week, and maintained at $30-21^{\circ} \mathrm{C}$ (daynight) in moist and humid terraria. Adult E. coqui were captured at the El Verde Field Station, Puerto Rico, under permits (DRNA: 01-IC-34; 02-IC-067; 03-IC-065) issued by the Departmento de Recursos Naturales, Puerto Rico. Embryos were staged according to Townsend and Stewart (TS 1-15; 1985) that describes and characterizes 15 embryonic stages from oviposition to 
hatching and has been instrumental in nearly all of the developmental studies on E. coqui. Care of all the animals was conducted in accordance with the regulations of the National Institutes of Health Guide for the Care and Use of Laboratory Animals and the University of Michigan UCUCA.

\section{Immunocytochemistry}

Embryos were anesthesized using a benzocaine $(0.001 \%)$ solution and fixed with $4 \%$ paraformaldehyde in a $0.1 \mathrm{M}$ phosphate buffer solution (PBS), $\mathrm{pH} 7.4$ for $4 \mathrm{~h}$ and the brains were prepared for either paraffin embedding or frozen (cryostat) sectioning.

\section{Paraffin sections}

Skulls were rinsed in 0.1 M PBS (pH 7.4), dehydrated, cleared, and embedded with paraffin. Brains were sectioned at $10 \mu \mathrm{m}$ using a rotatory microtome and mounted on slides, deparaffinized, rehydrated in an ethanol series, and placed into three changes of $0.1 \mathrm{M}$ PBS ( $\mathrm{pH}$ 7.4). Slides were placed in a peroxide solution (60 $\mathrm{ml} \mathrm{3 \%}$ peroxide/140 $\mathrm{ml} \mathrm{PBS}$ ) for $10 \mathrm{~min}$ to quench endogenous peroxidase activity and rinsed in $0.1 \mathrm{M}$ PBS $(\mathrm{pH}$ 7.4). Normal goat serum (10\% NGS, Vector Laboratories) was applied to the tissue on the slides for $15 \mathrm{~min}$ at room temperature. The tissue was incubated with primary antisera, rabbit anti-serotonin (Dilution 1:100; Protos Biotech Corporation), which is highly specific to formaldehyde-fixed serotonin (Janušonis 2004), and in 0.1 M PBS (pH 7.4) overnight at $4^{\circ} \mathrm{C}$ in a humidity chamber. Following the primary incubation, slides were rinsed in PBS and the brain tissue incubated for $1 \mathrm{~h}$ in a biotinylated goat anti-rabbit secondary (Dilution 1:200; Vector Laboratories). Slides were rinsed in PBS and then exposed to an avidin-biotin reagent (ABC Elite Kit, Vector Laboratories) for $1 \mathrm{~h}$, again rinsed in PBS, and then reacted with diaminobenzidine tetrahydrochloride (DAB; Sigma) and hydrogen peroxide.

\section{Frozen sections}

Frozen brains were placed in a $0.1 \mathrm{M} \mathrm{PBS} / 10 \%$ sucrose solution until they sank, then again in $0.1 \mathrm{M} \mathrm{PBS} / 20 \%$ sucrose solution until they sank, embedded in a mixture of $20 \%$ sucrose $/ 5 \%$ gelatin or O.C.T. compound, frozen on dry ice, and sectioned at $20 \mu \mathrm{m}$ on a sliding microtome. Brain slices were then rinsed in three changes of 0.1 M PBS (pH 7.4). Free-floating sections were placed in a peroxide solution ( $60 \mathrm{ml} \mathrm{3 \%}$ peroxide $/ 140 \mathrm{ml}$ PBS) for $10 \mathrm{~min}$ to quench endogenous peroxidase activity and rinsed in 0.1 M PBS ( $\mathrm{pH}$ 7.4). Normal goat serum $(10 \%$ NGS, Vector Laboratories) was applied to the tissue for $15 \mathrm{~min}$ at room temperature. Sections were incubated with primary antisera, rabbit anti-serotonin (Dilution 1:100; Protos Biotech Corporation) and 0.3\% Triton X-100 in PBS overnight at $4^{\circ} \mathrm{C}$ in a humidity chamber. Subsequent to primary incubation, sections were rinsed in PBS and incubated for $1 \mathrm{~h}$ in a biotinylated goat anti-rabbit secondary (Dilution 1:200; Vector Laboratories). Sections were rinsed in PBS and then exposed to an avidin-biotin reagent (ABC Elite Kit, Vector Laboratories) for $1 \mathrm{~h}$, rinsed again in PBS, and then reacted with diaminobenzidine tetrahydrochloride (DAB; Sigma) and hydrogen peroxide.

Controls for both approaches included the following: (1) substitution of rabbit serum for the primary antisera (rabbit anti-serotonin), (2) exposing the primary antisera (anti-serotonin) with a high concentration of serotonin, (3) omission of the primary antibody, and (4) substitution of PBS for the secondary antiserum and DAB. All controls displayed results that the primary antiserum was highly specific to formaldehyde-fixed serotonin.

\section{Serotonin-immunoreactivity}

The antibodies against serotonin used in the present study revealed a pattern of immunostaining in the brain that was consistent among frogs of the same stage. Both paraffin embedded tissue and free-floating sections produced quality immunostaining and essentially no difference was noted between the two methods. In this report, serotonin cells and fibers are first described when immunopositive staining is initially detected. However, it should be noted that although immunohistochemistry detects serotonergic cells at specific points in development these cells may have been present before immunodetection. Many neurons that produce neurotransmitters either migrate before they become fully functional and/or require time and maturation to express the transmitter phenotype (Verney 2003; Patel and Zhou 2005). Anatomical terminology came from the following reports: Adli et al. (1999), Opdam et al. (1976), Scalia (1976), and Neary and Northcutt (1983).

\section{Results}

TS 6-8

The first densely immunoreactive neurons are detected in the developing rhombencephalon at TS 6 (Fig. 1a, d). Clusters of serotonergic cells occur in the raphe nuclei, located on both sides of the midline. Morphologically, serotonergic cells are primarily round to ovoid with some possessing short immunoreactive processes that are typically oriented in a mediolateral direction. By TS 7 in the rostral rhombencephalon region, immunopositive cells are visible in the developing reticular nuclei (Fig. 1c). These serotonergic cells are located in the ventrolateral portion of the brain stem, lateral to the 
Fig. 1 a-e Serotonergic development in

Eleutherodactylus coqui in the hypothalamus and hindbrain regions at TS 6-8. a Schematic drawing displaying a sagittal section through the brain of $E$. coqui at TS 8 illustrating the position of serotonergic neurons (black ovals) and fibers (lines) and the location of transverse sections taken for figures (b-e) $O T$, optic tectum; $P V O$, paraventricular organ; $R a I$, inferior raphe nuclei; $R a S$, superior raphe nuclei; bar $=$ $200 \mu \mathrm{m}$. b Transverse section through the hypothalamus of E. coqui at TS 7 displaying immunopositive neurons and processes (arrow). v, third ventricle; $b a r=45 \mu \mathrm{m}$. c Transverse section of the hindbrain displaying immunopositive cells in the developing superior raphe $(R a S)$ and reticular $(R t)$ nuclei at TS 7. v, fourth ventricle; bar $=75 \mu \mathrm{m}$. d Immunopositive neurons in the caudal portion of the inferior raphe nuclei $(R a)$ and serotonergic fibers located in the lateral and ventrolateral regions (arrowheads). v, fourth ventricle; transverse section; bar $=75 \mu \mathrm{m}$. e Transverse section displaying delicate

immunopositive fibers running caudally in the ventral portion of the developing hindbrain (arrows). $v$, fourth ventricle; bar $=60 \mu \mathrm{m}$ a

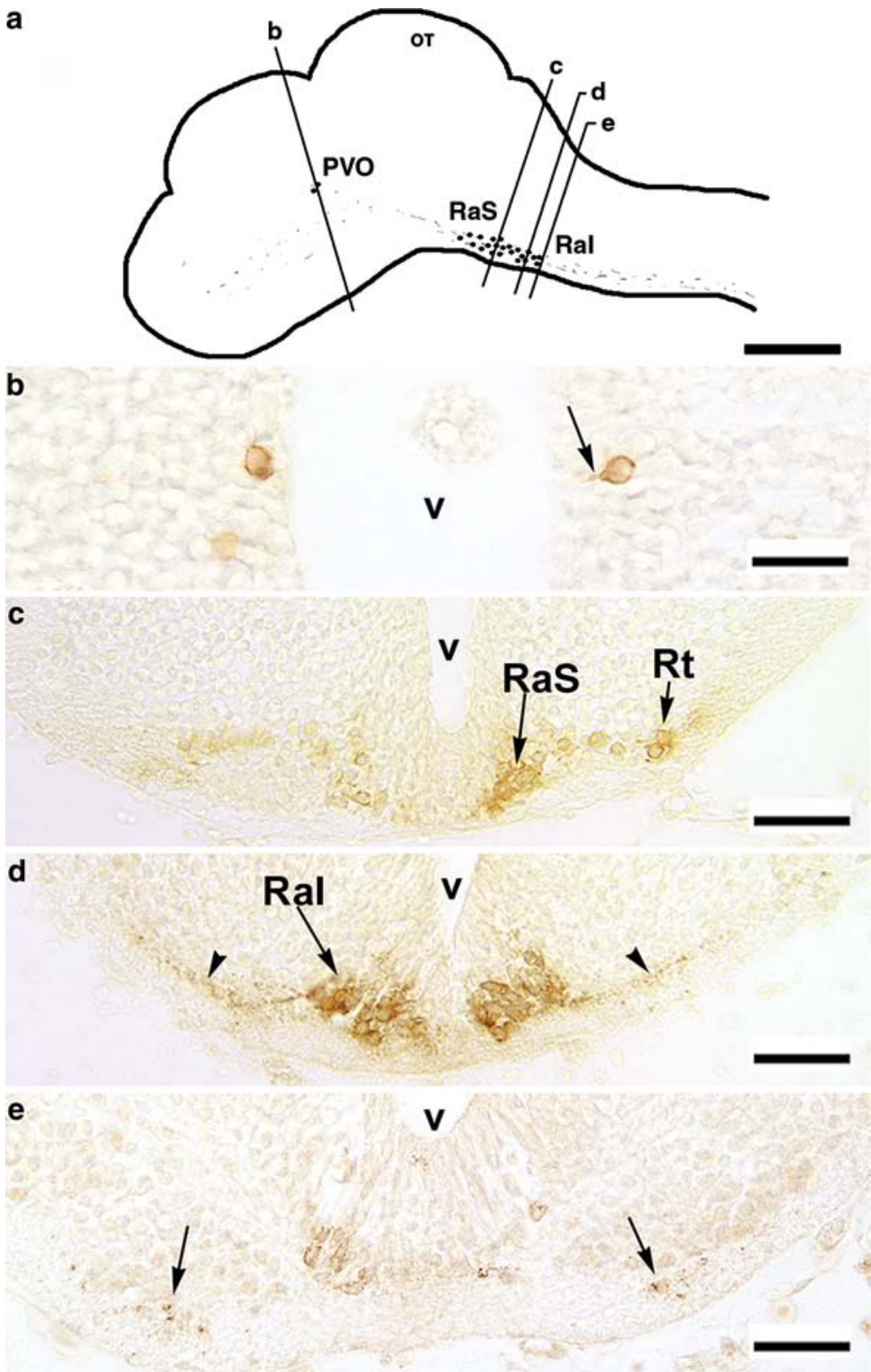

superior raphe. Morphologically, these neurons are round to ovoid, and some possess small, mediolaterally oriented immunostained processes. Serotonergic fibers are present in the raphe and reticular nuclei, between the two nuclei, and laterally along the ventral border of the brain (Fig. 1a, d). However, no immunoreactive fibers cross the midline and contact contralateral serotonergic cells in the hindbrain. Immunopositive fibers also project rostrally to the lateral and ventrolateral portions of the forebrain (Fig. 1a) and caudally to the rostral and mid spinal cord regions (Fig. 1a, e).

The most rostral group of serotonergic neurons is detected at TS 7 in the primordium of the paraventricular organ in the hypothalamus (Fig. 1a, b). The number of serotonergic cells at this stage of development in the paraventricular organ ranges between two and four per embryo. The cells are ovoid, possess short immunopositive processes (most oriented horizontally), and are located at the surface of the third ventricle, adjacent to the ependymal layer, or one to two cell layers deep.

By the termination of TS 8 , the number of serotonergic neurons increases to six to eight per embryo in the paraventricular organ, where a few (1-2) immunopositive cells occur in the posterolateral portion of the paraventricular organ adjacent to the nucleus infundibularis. In the rhombencephalon, serotonergic cells of the superior raphe nuclei form two triangular groups of cells lateral to the midline. Rostrally, these cells overlap with the laterally located immunoreactive cells in the developing reticular nuclei at the mesencephalon-rhombencephalon border, and caudally, abut with the serotonergic cells of the inferior raphe nuclei at the midline of the brain stem in the region of the developing cerebellum. The inferior raphe nuclei form two dense, vertical columns of immunostained cells (Fig. 1d) that merge together at the midline near the ventral surface. 
The number of serotonergic cells in the superior raphe nuclei is greater than the number in the reticular or the inferior raphe nuclei. Numbers of immunopositive fibers remain low but are most persistent in the lateral regions surrounding the developing reticular and superior raphe nuclei.

TS 9-12

The number of immunopositive cells continue to increase in the paraventricular organ. Cells are either flush with the ependymal layer of the third ventricle or one to two cells deep, and are located in the ventral one-third of the developing third ventricle (Fig. 2a, b). Cells display short processes (unipolar or bipolar) that are oriented mediolaterally. By TS 10, immunoreactive processes from the neurons in the paraventricular organ appear to contact, or are in close proximity to the cerebrospinal fluid of the third ventricle.

At TS 10, numbers of serotonergic cells in the reticular nuclei increase slightly and continues to be distributed in lateral locations in the developing ventral mesencephalon-rhombencephalon. Increases in the immunopositive cells also occur in the superior raphe nuclei that remain as two groups of neurons straddling the midline (Fig. 2c). Serotonergic cells at the rostral end of the superior raphe remain medially adjacent to the immunopositive cells of the reticular nuclei. The serotonergic cells at the caudal end of the superior raphe form an essentially continuous longitudinal line of cells with the inferior raphe neurons (Fig. 2a). Cells in the inferior raphe also exist in two columns (Fig. 2d), but eventually merge into one at the midline in the developing myelencephalon.

By TS 12, the width of the third ventricle in the region of the paraventricular organ decreases as the volume of the hypothalamus increases during development. The number of serotonin cells in the paraventricular organ increases twofold from TS 10 (Fig. 3a, b). These cells are intensely stained, and are two or three cells deep, lining the ependymal wall of the third ventricle in the paraventricular organ. Immunoreactive processes are visible projecting from these cells into the ventricle and contacting cerebrospinal fluid (Fig. 3b). Immunopositive cells increased in the caudal paraventricular organ, and a chain of serotonergic cells, spanning rostral to caudal is present within this nucleus (Fig. 3c).

The number of serotonergic cells continues to increase gradually, approximately $50 \%$ more than TS 10 in both reticular and raphe nuclei (Fig. 3a, d). Serotonergic cells in the reticular nuclei have continued to extend laterally in the brain and are dispersed in the ventral and ventrolateral mesencephalic and metencephalic regions (Fig. 3d). Serotonergic cells of the superior raphe nuclei continue to straddle the midline of the brain and remain continuous with the serotonergic cells of the inferior raphe nuclei, which continue as the most caudal immunopositive neurons. Numbers of immunoreactive fibers increase in the hindbrain. A delicate network of varicose fibers surrounds immunopositive and non-labeled cells in the reticular and raphe nuclei, and spans across the ventral (including the interpeduncular nucleus), ventrolateral, and lateral hindbrain regions.

\section{TS 13-15}

The later stages of embryogenesis are characterized by the formation of distinct serotonergic hindbrain nuclei and extensive increases in serotonergic cells and fibers. The number of serotonin cells in the paraventricular organ increases approximately $150 \%$ by TS 13 and $300 \%$ by TS 15 and forms multiple layers around the circumference of the ventricle. These cells are densely immunostained, with processes projecting medially into the third ventricle. Serotonergic cells also increase in the caudal portion of the paraventricular organ, adjacent to the nucleus infundibularis. By TS 15, a continuous line of serotonergic cells, posterolaterally oriented, spans the entire rostral-caudal axis of the paraventricular organ (Fig. 4a, b).

By TS 13, serotonergic immunoreactive cells form discrete clusters within specific reticular nuclei starting at the level of the optic tectum in the mesencephalon. Serotonin neurons are present and abundant within the nuclei reticularis pontis oralis pars medialis and pars lateralis along the ventral and ventrolateral margin of the developing brain stem (Fig. 5b, d). Many of these serotonergic cells have dendritic arborizations oriented in a dorsomedial-to-ventrolateral direction (Figs. 4c, 5d). Serotonin cells are also found within the nuclei reticularis paragigantocellularis, reticularis magnocellularis, and reticularis gigantocellularis (Fig. 5b, d). These immunopositive cells are closer to the midline than other reticular serotonin cells and most possess horizontally oriented processes. Serotonin cells within these reticular nuclei are clustered close together and adjacent to the serotonergic cells of the superior raphe nuclei.

Immunopositive cells are also visible in the superior raphe nuclei adjacent on either side of the midline, at the level of the caudal mesencephalon, and extend to the level of the cerebellum where they merge with serotonergic cells of the inferior raphe nuclei (Figs. 4a, 5a). Serotonin cells within the rostral portion of the superior raphe are essentially arranged as two columns, but then blend together in the caudal region prior to their union with the serotonin cells in the inferior raphe (Fig. 4d, e). Many of these caudal perikarya have vertically oriented possesses, some of which project dorsally to the fourth ventricle (Fig. 5b, c) and ventrally to the white matter of the brain stem (Fig. 4d). Likewise, immunostained cells in the inferior raphe nucleus also have vertical processes, which are ventrally directed (Fig. 4e). By TS 15, a continuous cluster of serotonergic cells spans from the superior 
Fig. 2 a-d Serotonergic development in E. coqui in the hypothalamus and hindbrain regions at TS 10. a Schematic drawing displaying a sagittal section through the brain of $E$. coqui at TS 10 illustrating the position of serotonergic neurons (black ovals) and fibers (lines) and the location of transverse sections for figures (b-d). OT, optic tectum; PVO, paraventricular organ; RaI, inferior raphe nuclei; $R a S$, superior raphe nuclei; $b a r=$ $200 \mu \mathrm{m}$. b Transverse section through the hypothalamus of $E$. coqui at TS 10 displaying the increase in immunopositive neurons in the paraventricular organ since TS $7 . v$, third ventricle; $b a r=45 \mu \mathrm{m}$. c Transverse section displaying the distribution of serotonergic cells in the developing superior raphe nuclei $(R a S)$; bar $=$ $60 \mu \mathrm{m}$. d Transverse section in the rhombencephalon displaying two columns of serotonergic neurons in the inferior raphe nuclei $(R a I)$. bar $=60 \mu \mathrm{m}$
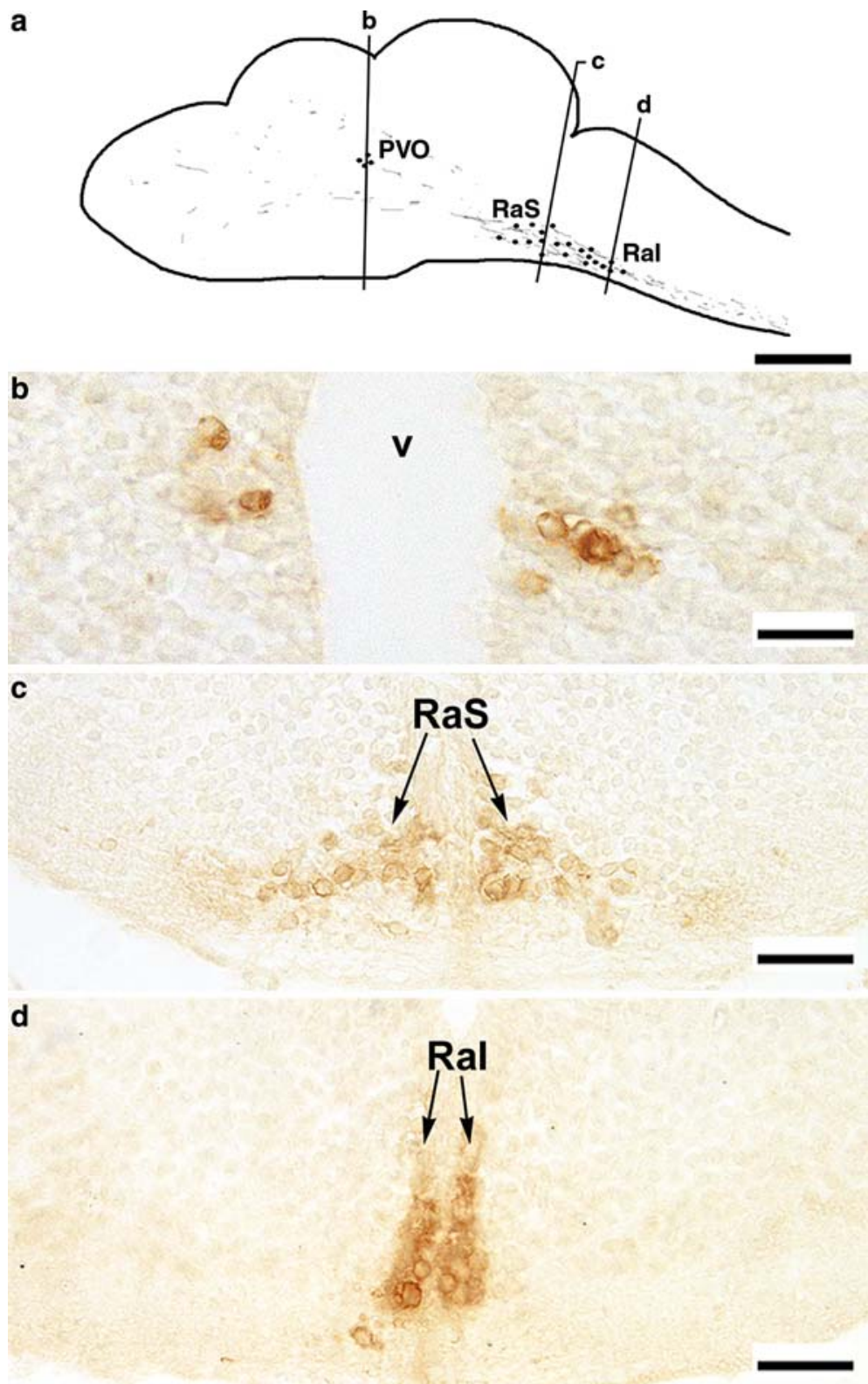

raphe nuclei rostrally and terminates in the inferior raphe nuclei at the level of the obex (Figs. 4a, 5a).

Numerous serotonergic varicosities are present in the interpeduncular nucleus (Fig. 4d). Within this nucleus, varicosities are dense, and vertically oriented immunostained processes span dorsoventrally through the nucleus to the serotonergic cells of the superior raphe nuclei. Also, dense accumulations of varicose fibers are present in the solitary nucleus (Fig. 4e). Immunostained fibers occur past the level of the obex and project caudally in the white matter of the ventral and ventrolateral zones of the spinal cord. Increases in the serotonergic fibers are substantial in the hindbrain but are also very numerous in telencephalic and diencephalic regions (Figs. 4a, 5a).

\section{Discussion}

This immunocytological study examined the ontogeny of the central serotonergic system in the directly developing frog, E. coqui. This anuran lacks the free-swimming, larval stage (tadpole) typical of most frogs and directly develops into the adult phenotype. Initial serotonergic neurons occur at TS 6 (early-mid embryogenesis) in the developing raphe nuclei of the rhombencephalon. Serotonergic perikarya are located in the paraventricular organ of the hypothalamus and in the reticular nuclei of the hindbrain at TS 7. Immunopositive fibers are detected in the hindbrain, hypothalamus, and lateral forebrain regions shortly after the appearance of the initial serotonin cells (TS 6-7). Serotonergic neurons, fibers and varicosites 
Fig. 3 a-d Serotonergic development in E. coqui in the hypothalamus and hindbrain regions at TS 12. a Schematic drawing displaying a sagittal section through the brain of $E$. coqui at TS 12 illustrating the position of serotonergic neurons (black ovals) and fibers (lines) and the location of transverse sections for figures b-d. $O T$, optic tectum; $P V O$, paraventricular organ; RaI, inferior raphe nuclei; $R a S$, superior raphe nuclei; bar $=$ $200 \mu \mathrm{m}$. b Immunopositive neurons in the paraventricular organ at TS 12. Neuronal processes (arrows) are visible in the third ventricle presumably contacting cerebral spinal fluid; bar $=30 \mu \mathrm{m}$. c Transverse section through the caudal hypothalamus displaying a line of serotonergic cells spanning posterolaterally in the paraventricular organ. $v$, third ventricle; $b a r=60 \mu \mathrm{m}$. d Transverse section of the ventral portion of the mesencephalon-metencephalon border displaying

immunopositive neurons in the superior raphe $(R a S)$ and reticular $(R t)$ nuclei. The developing reticular nuclei are expanding laterally but differentiation into specific nuclear groups has not yet occurred; bar $=75 \mu \mathrm{m}$
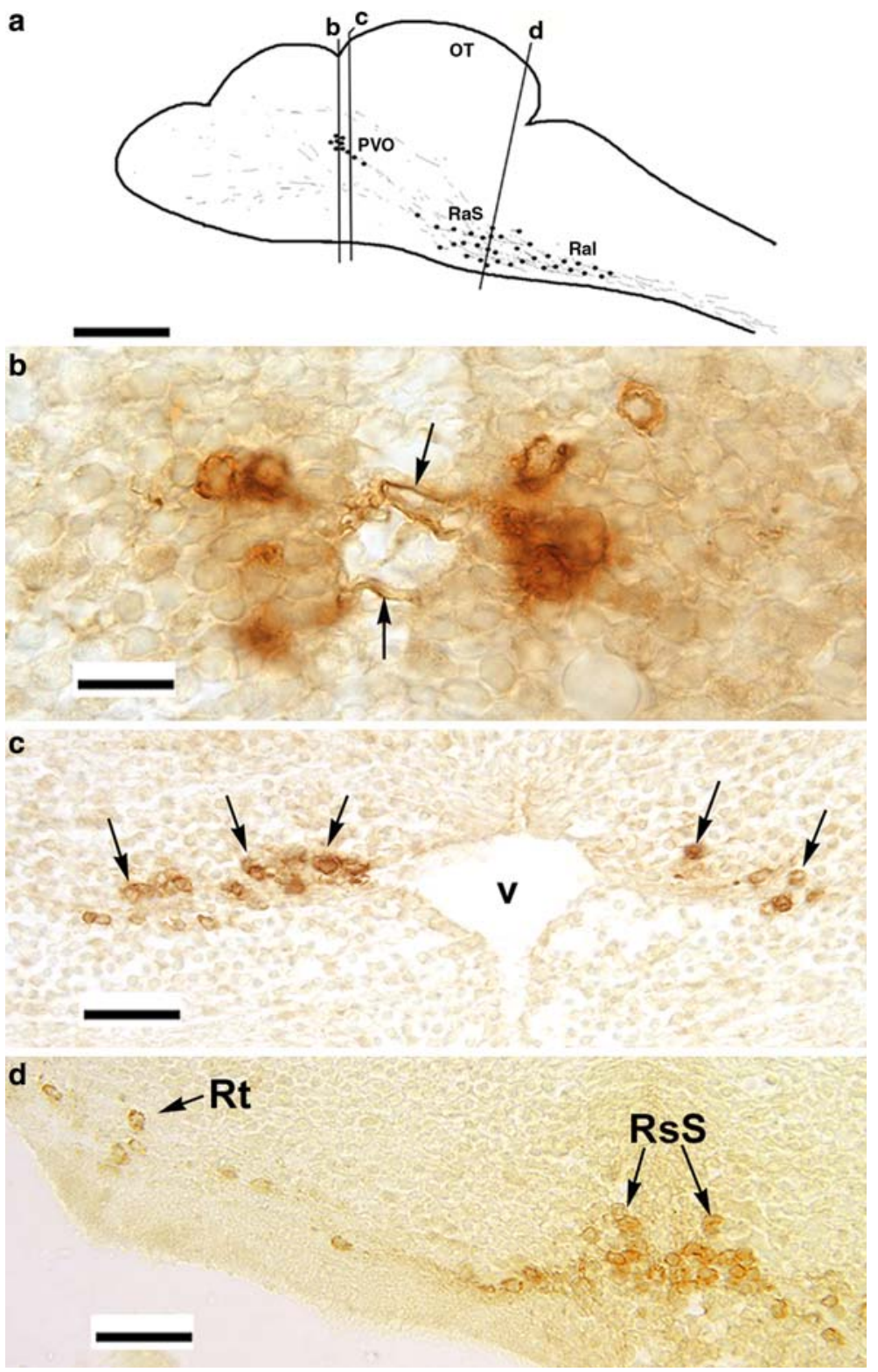

gradually increase during early-mid to mid embryonic development. However, during the latter stages of embryogenesis (TS 13-15) substantial growth in the serotonergic system takes place. This growth includes increased numbers of serotonin cells in the paraventricular organ, reticular, and raphe nuclei, differentiation of reticular nuclei, and a dramatic bloom of serotonergic fibers and varicosities in the brain.

\section{Vertebrate serotonergic development}

Vertebrate lineages display similar neuroanatomical patterns in serotonergic development; however, differences are noted to the relative timing and the temporal sequence of serotonergic structures, especially in the diencephalic nuclei. In tetrapods, the first immuno- stained serotonergic cells occur in the hindbrain. Investigations in the rat indicate that the first immunopositive cells occur in the superior raphe nuclei (B5-B9) in the midbrain and pons by E13 (gestation = 21 days; E1E21). Detection of serotonergic neurons in the medulla or inferior raphe group (B1-B3) occurs 1-2 days following the initial appearance of the B4-B9 complex (Lidov and Molliver 1982; Wallace and Lauder 1983). In the mouse, the first immunopositive perikarya are detected at E12.5 (gestation = 21 days; E1-E21) in the hindbrain (Ballion et al. 2002). Serotonergic cells develop early in chicken with the first immunopositive cells occurring at E4 (incubation = 21 days; E1-E21), and by E5, serotonergic cells are observed throughout the brain stem (Wallace 1985; Sako et al. 1986; Okado et al. 1992). Initial immunopositive cells in E. coqui appear at TS 6; embryonic development is divided into 15 stages 
a
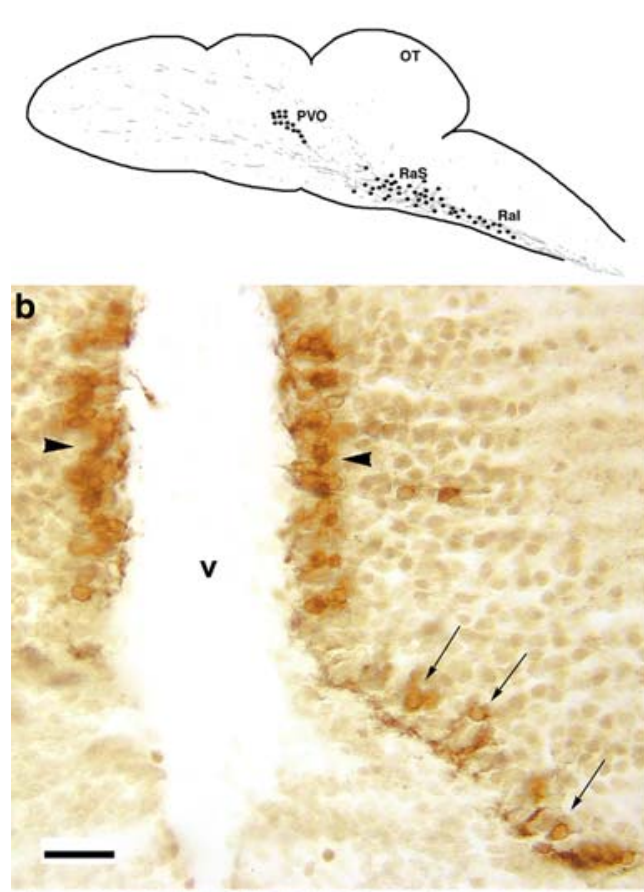

d

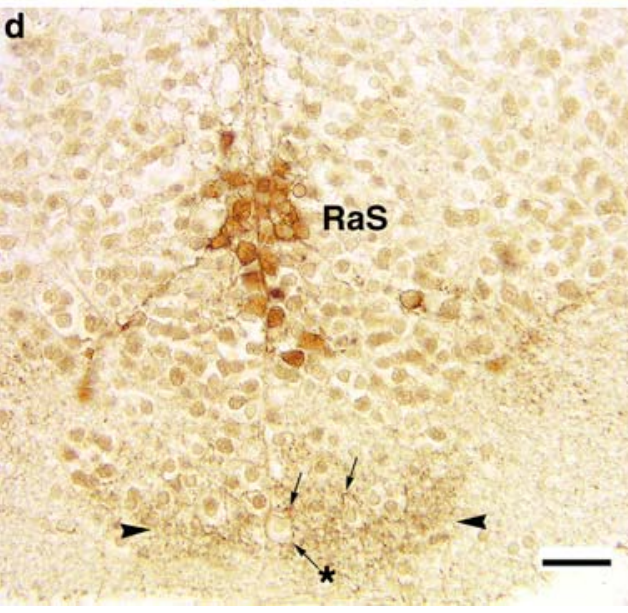

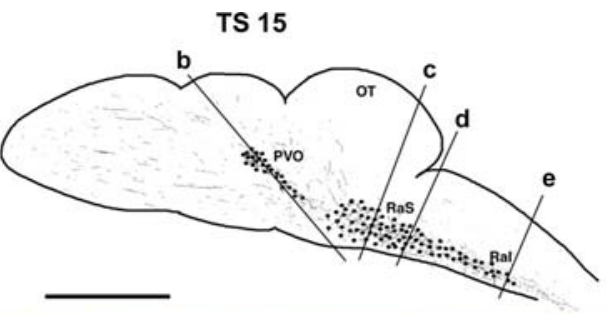
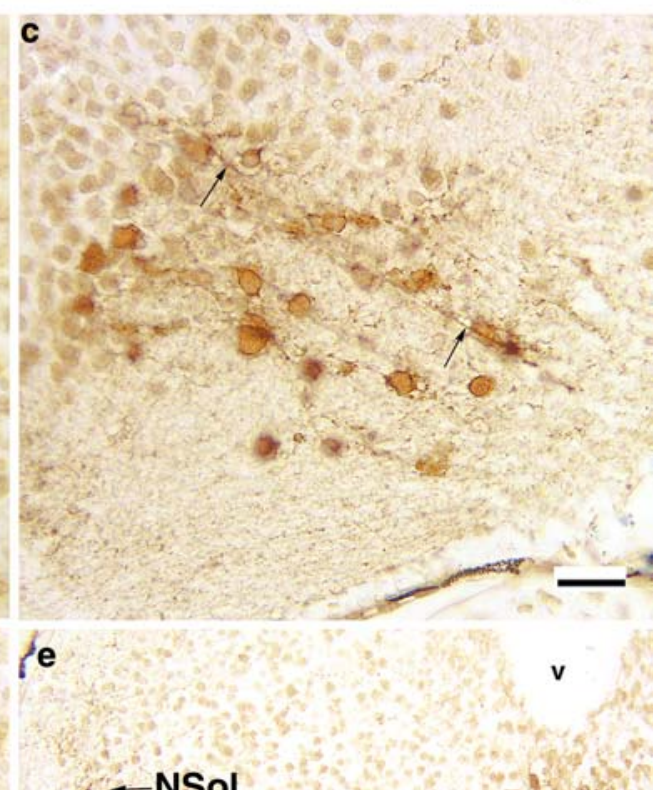

- NSol

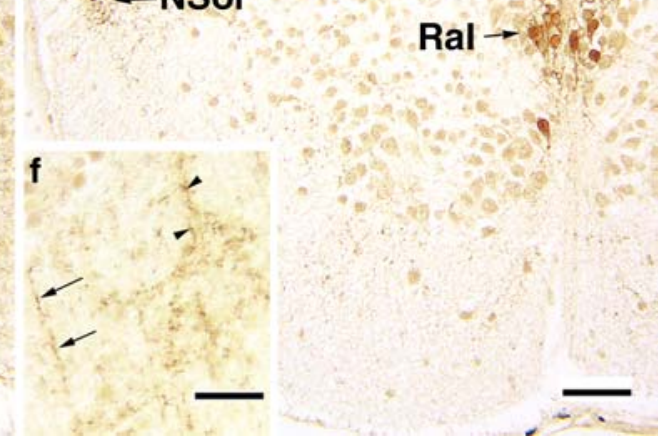

Fig. 4 a-f Serotonergic development in E. coqui in the hypothalamus and hindbrain regions during late embryogenesis. a Schematic drawing displaying sagittal sections through the brain of $E$. coqui at TS 13 and TS 15 illustrating the increase and position of serotonergic neurons (black ovals) and fibers (lines) and the location of transverse sections for figures (b-e) at TS 15. OT, optic tectum; PVO, paraventricular organ; RaI, inferior raphe nuclei; $R a S$, superior raphe nuclei; bar $=250 \mu \mathrm{m}$. b The paraventricular organ has several layers of serotonin cells (arrowheads) surrounding the third ventricle. A posterolateral line of immunopositive neurons (arrows) is also present. $v$, third ventricle; transverse section; bar $=50 \mu \mathrm{m}$. $\mathbf{c}$ A high magnification of the nucleus renticularis pontis oralis, pars medialis $(\mathrm{RPoOm})$ displaying dorsomedial-to-ventrolateral dendritic orientation. Numerous varicose fibers (arrows) and processes are present. transverse section; bar $=30 \mu \mathrm{m}$. d Immunostained neurons of the superior raphe nuclei $(R a S)$ exhibit ventrally oriented processes and numerous varicose fibers. The nucleus interpeduncularis (between arrowheads) is laden with immunostained fibers (arrows), some that encircle non-labeled cells (arrow with asterisk). $v$, ventricle; transverse section; bar $=50 \mu \mathrm{m}$. e Transverse section displaying the caudal region of the hindbrain with immunopositive neurons present in the inferior raphe nucleus ( RaI). A cluster of immunostained serotonergic fibers are present in the nucleus solitaries $(N S o l)$. $v$, fourth ventricle; bar $=65 \mu \mathrm{m}$. f High magnification of the lateral hypothalamus at TS 13 displaying immunopositive fibers (arrows) and varicosities (arrowheads); transverse section; bar $=15 \mu \mathrm{m}$

(Townsend and Steward 1985), and TS 6 correlates to approximately $33 \%$ of embryonic development (each stage is not temporally equal). Judging or comparing only the stage number, chick serotonergic development appears much earlier than other vertebrates since, E4 correlates approximately to $19 \%$ of embryogenesis, compared to $\sim 33 \%$ (TS 6 ) in E. coqui, $\sim 60 \%$ (E12.5) in the mouse, and $\sim 62 \%$ (E13) in the rat. However, if serotonergic development is compared with another developmental event, e.g., somite development, a different prospective appears. At TS 6 in E. coqui, all somites have segregated and are undergoing differentiation (Schlosser and Roth 1997b), at E4 in chicks, all somites have also segregated, at E12.5 in the mouse, 
a
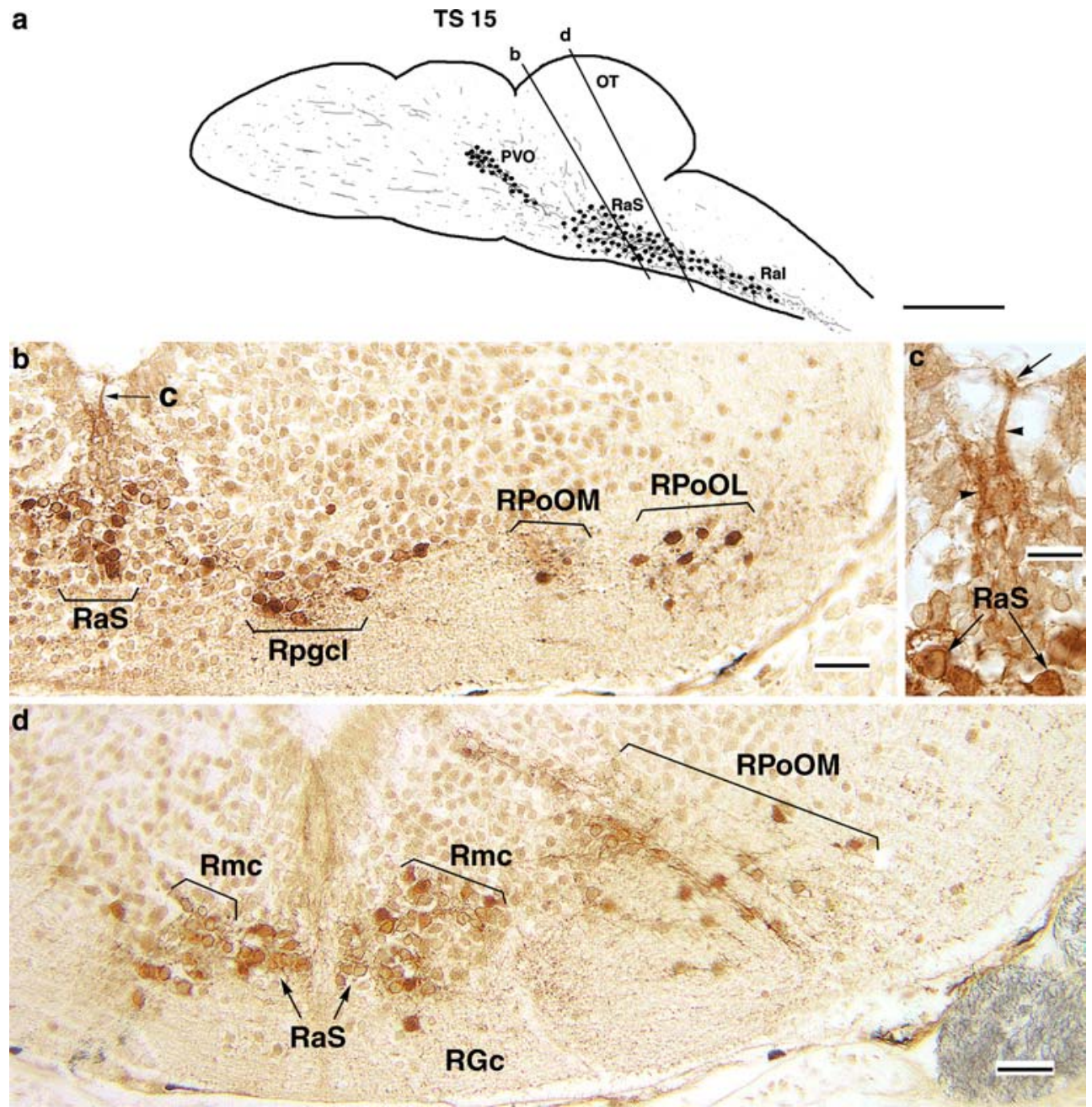

Fig. 5 a-e Serotonergic development in E. coqui during the final stage in embryogenesis, TS-15. a Schematic drawing of a sagittal section through the brain of E. coqui at TS 15 displaying the abundance and position of serotonergic neurons (black ovals) and fibers (lines), and the location of transverse sections for (b) and (d). OT, optic tectum; PVO, paraventricular organ; RaI, inferior raphe nuclei; RaS, superior raphe nuclei; $b a r=250 \mu \mathrm{m}$. b A low magnification photomicrograph of the hindbrain displaying the serotonergic cells in the newly differentiated reticular nuclei. The nuclei reticularis pontis oralis pars medialis $(R P O O M)$ and pars lateralis $(R P o P L)$ occur in the more lateral regions and the nuclei reticularis paragigantocellularis dorsalis $(R p g c d)$ and lateralis $(R p g c l)$ are in more medial locations and closer to the superior raphe $(R a S) ; b a r=50 \mu \mathrm{m}$. c An enlargement of a immunostained process (arrowheads) in the hindbrain leading to the ependymal surface (arrow) in the fourth ventricle. Immunopositive cells from the superior raphe nucleus $(R a S)$ are also visible; bar $=$ $20 \mu \mathrm{m}$. d A low magnification photomicrograph of the hindbrain displaying the laterally located nucleus reticularis pontis oralis, pars medialis $(R P o O M)$, the more medially oriented nucleus reticularis magnocellularis $(\mathrm{Rmc})$, one large serotonergic neuron in the nucleus reticularis gigantocellularis $(R G c)$, and the superior raphe group $(R a S) ; b a r=50 \mu \mathrm{m}$

somites 52-54 of 60 segregate, and at E13 in the rat, somites $46-48$ of 65 are segregating. Thus, using somite development as a reference point, hindbrain serotonergic development is relatively earlier (slightly) in rats, and to some extent in mice, than the chick or $E$. coqui.

In contrast to the brain stem regions, hypothalamic serotonergic cells appear later in both chickens and E. coqui. Serotonergic cells are absent in the hypothalamus during development in mammals. In chicks, cells are detected in the paraventricular organ between E9E12 (Wallace 1985) or E10 (Sako et al. 1986), which correlates around the time of toe phalange development and increase in toe length. In $E$. coqui, immunopositive cells occur in the paraventricular organ at TS 7 which is concurrent with digit development as well (Townsend and Steward 1985). Thus, in E. coqui and chicks hypothalamic cells develop or at least become immunopositive for serotonin around the time of limb development.

Teleost possess the general vertebrate serotonergic design, containing clusters of neurons in the hindbrain (superior and inferior raphe) and diencephalon. In the zebrafish (Danio rerio), immunopositive serotonergic neurons are first detected in the diencephalon (posterior tuberculum) one day after fertilization $(\sim 33 \%$ of embryonic development) and in the superior raphe nuclei after two days $(\sim 66 \%$ of embryonic development) (McLean and Fetcho 2004). After 3 days, during which time hatching takes place, the raphe neurons already 
project to the 10th-15th myotomal level. The initial appearance of serotonergic cells (posterior tubuculum) occurs after all somites have segregated (Kimmel et al. 1995). Again using somite development as a reference point, this development correlates temporally more with the chick and E. coqui than mammals, at least with rats and mice. Variations in serotonergic development certainly exist among teleost fish and they also display some disparity from tetrapods (Ekström et al. 1985; Bolliet and Ali 1992; Bolliet et al. 1994). Diencephalic nuclei are typically (but not always) the first to contain serotonergic cells and there is a broad temporal range for the initial appearance of serotonergic cells, which is at least partially connected to differences in temperature during embryonic development.

Fiber development in E. coqui also commences shortly after the appearance of serotonin perikarya, and by TS 8 , fibers are visible in the lateral diencephalon, in the hindbrain surrounding the raphe nuclei, and projecting caudally in the spinal cord. Numbers of serotonergic fibers and varicosities gradually increased throughout early-mid and mid embryonic stages. However, substantial increases in fibers and varicosities occurred at TS 13 and continued throughout the late embryonic stages TS 14-15. The amount of serotonergic growth that transpired during late embryogenesis was similar to what occurs in aves (Wallace 1985) and mammals (Lidov and Molliver 1982; Wallace and Lauder 1983) but takes place during the late embryonic stages, not mid-late, and over a somewhat shorter time span. In the teleost fish, fiber development also occurs during embryogenesis and both ascending and descending tracks are well-developed by the time of hatching in most taxa (Ekström et al. 1985; Bolliet and Ali 1992; Bolliet et al. 1994; McLean and Fetcho 2004). In fact, the serotonergic system is one of the first neurotransmitter systems to develop in the zebrafish whereby, immunopositive fibers are detected very early in development.

Variations in vertebrate ontogeny exist but an important factor is that most components of the serotonergic system are recognized prior to the birth or hatching regardless of the state of the embryo, whether precocial (chicks and E. coqui) or altricial (rats and mice). In fact, the system is developed enough in mice at E16.5 to elicit serotonin-induced rhythmic motor activity prior to birth (Ballion et al. 2002) and newly hatched zebrafish larvae have major aminergic transmitters systems functioning while the fish elicits many behaviors including locomotion and predator avoidance (McLean and Fetcho 2004). Similarly, if the newly hatched $E$. coqui neonates are subjected to potential threats they have the physiological capability to flee from the nest site, at which they normally remain for 3-5 days (personal observation). This should not infer that postembryonic development and maturation does not occur in the serotonergic system because such changes do occur in vertebrates. Many synaptic connections and receptor expressions require additional time for development (Okado et al. 1992). Further physiological adjustments and maturations also occur following the birth or hatching in rat, chick, and mouse brains (Rajaofetra et al. 1989; Summers et al. 1991; Okado et al. 1992; Ekström 1994; Ballion et al. 2002). In fact, alterations in serotonin metabolism and increases in varicose fibers are detected in E. coqui after hatching (Ten Eyck et al. 2005). Nevertheless, whether neonates are proecocial or altrical, or needing subsequent physiological and/or morphological development, there appears to be selection in vertebrates for a complete and functioning serotonergic system at the time of birth or hatching.

Anuran serotonergic development: metamorphosing vs. directly developing frogs

The general anatomical pattern of the central serotonergic system in $E$. coqui is very similar to metamorphic frogs including Xenopus laevis and several ranid species (Parent 1973; Ueda et al. 1984; van Mier et al. 1986; Adli et al. 1999). Serotonergic groups are found in the superior and inferior raphe, reticular nuclear groups, and the paraventricular organ. Additionally, the neuroanatomical pattern of reticular nuclei in E. coqui is similar to R. pipiens in both neuronal characteristics and orientation of fibers, especially the reticular nuclei, pontis oralis pars medialis and lateralis, paragigantocellularis dorsalis and lateralis, magnocellularis, and gigantocellularis (Adli et al. 1999). Adli et al. (1999) found that ranid reticular formation is complex in organization and very similar to amniotes. In fact, these investigators hypothesized that many of the nuclei are homologous to mammalian nuclei and consequentially use mammalian terminology in their descriptions. This appears to indicate that anurans, both metamorphic and directly developing, share the apparent conserved tetrapod pattern of the reticular formation.

Similar to developing fish larva (McLean and Fetcho 2004), serotonergic development in $X$. laevis tadpoles occurs early and rapidly. Van Mier et al. (1986) discovered serotonergic neurons, some with caudally oriented processes, in the basal plate adjacent to the midline at stage NF 28 (Nieuwkoop and Faber 1956). At NF 28, somites 20-22 of $\sim 45$ have segregated in the developing tadpole when these initial serotonin cells appear, which makes serotonergic development in $X$. laevis earlier than any other vertebrate so far examined. In E. coqui, initial immunopositive cells appear at TS 6, which is after all the somites have segregated and are undergoing differentiation (Schlosser and Roth 1997b). Immunopositive processes appear shortly thereafter and descend into the spinal cord. Thus, with somite development as a reference point, hindbrain serotonergic development in E. coqui trails that of the metamorphic frog, X. laevis; however, both developmental modes display similar neuroanatomical organization and ontogenetic pattern.

Hindbrain serotonergic neurons are also detected early in the metamorphic frog, R. temporaria (Wool- 
ston et al. 1994). Similar to X. laevis, by the time of hatching (G 20; Gosner 1960) there is a large cluster of cells in the raphe nuclei of the hindbrain. Both ascending and descending axons from the raphe group are present in the brainstem and spinal cord, respectively. This study focused on the modulation of locomotor rhythmicity and found that serotonergic projections in the ventrolateral aspect of the spinal cord are present by the time tadpoles hatch. Several investigators have proposed that serotonin, as well as other monoamine transmitters, might be responsible for much of the flexibility of larval swimming or early locomotor activity that enables the larva to swim and avoid predators (Woolston et al. 1994; Sillar et al. 2002). E. coqui embryos are encapsulated in an egg covered by a gelatinous membrane, however, beginning at TS 6/7 embryos begin to thrash their tails and by TS 10, start to flex and twitch their legs (Townsend and Stewart 1985). This locomotor activity is initiated at the time when serotonergic perikarya are detected in hindbrain and both ascending and descending axons are present. Locomotion may also be enhanced due to the accelerated development of the spinal cord in E. coqui, especially between TS 4 and TS 9, where high levels of cell proliferation and neurogenesis occur as well as the early formation of the lateral motor columns (Schlosser 2003). Furthermore, by the time E. coqui hatches, the peripheral nervous system has innervated skeletal muscles (Schlosser and Roth 1997b). Thus, with the combination of accelerated development of the spinal cord, peripheral nerve innervation, and the presence of a serotonergic system (as well as other neurochemical systems, e.g., catelcholamines, unpublished data) movement occurs in these developing frogs even without a swimming tadpole stage.

Serotonergic cells are also detected in the hypothalamus, specifically the paraventricular organ, in metamorphic frogs and E. coqui (Parent 1973; Ueda et al. 1984; van Mier et al. 1986; Adli et al. 1999). Immunocytochemistry has demonstrated that processes of these serotonergic cells projected medially into the third ventricle, contacting cerebral spinal fluid (CSF). This has also been described in the case of the dorsal raphe nucleus of the embryonic rat (Lauder et al. 1982). Previous studies on catecholamine development in anurans also found neurons that possessed immunostained processes that contacted CSF (for review see Smeets and González 2000). The function of these processes is hypothesized as an uptake mechanism for neurochemicals from the CSF into the perikarya of neurons in nonmammalian vertebrates (Nakai et al. 1977; Smeets and González 1990; Smeets and Steinbusch 1990; Smeets et al. 1991; Boularand et al. 1998). Additionally, Lowry et al. (2003) demonstrated that serotonergic cells in the dorsomedial hypothalamus play an important role in the differential stress responsiveness in Lewis and Fischer rats.
Metamorphosing vs. directly developing frogs: developmental considerations

Metamorphosis is a life history period characterized by dramatic ecological, morphological, and physiological transformations (Gilbert et al. 1996; Tata 1996). During metamorphosis a substantial increase of serotonin cells occurs in both hypothalamic and hindbrain nuclear groups along with increases of serotonergic fibers and varicosities in the brain (van Mier et al. 1986). Concentrations of monoamines and their metabolites fluctuate during metamorphosis (Norris et al. 1992; Takeda 1997) but levels of serotonin are highest during the climax of metamorphosis in the frogs, B. bufo and $R$. $n i$ gromaculata (Takeda 1997). Interestingly, levels of serotonin are highest during the late stages of embryogenesis in E. coqui (Ten Eyck et al. 2005). Metamorphosis and the later stages in direct development share an important characteristic: the rapid increase in serotonergic development within a relatively short temporal period. Another alteration that occurs in the serotonergic system during metamorphosis includes a change in serotonergic modulation of respiratory motor output for gill and lung ventilation (Kinkead et al. 2002). Taken together, the events that occur during metamorphosis (or late embryogenesis) may indicate that serotonergic development is associated with, or dependent upon, thyroid hormone or other neurohormonal factors.

Jennings and Hanken (1998) examined thyroid gland development in E. coqui and found that the gland develops early (TS 10) and shortly thereafter, begins to accumulate follicular colloid. These morphological changes are comparable to metamorphic frogs but typically occur around the time of metamorphosis. Furthermore, a study examining thyroid hormone receptors, $\operatorname{TR} \alpha$ and $\operatorname{TR} \beta$, in $E$. coqui found that the thyroid hormone receptor, $\operatorname{TR} \beta$, is up-regulated starting at TS 10 and then dramatically increases during the later stages (TS 12-15) of embryogenesis (Callery and Elinson 2000a). This metabolic event is similar to what transpires during the climax of metamorphosis (Shi 1996; Tata 1996), indicating that directly developing frogs still undergo a $\mathrm{T}_{3}$-dependent developmental period. Thyroid gland maturation and expression of $\mathrm{TR} \beta$ mRNA occur just prior to the expansion and maturation of the serotonergic system. These correlated developmental events also occur in $X$. laevis, not during embryogenesis, but during metamorphosis, when the serotonergic system is rapidly maturing. Additionally, it has also been demonstrated that thyroid hormone promotes up-regulation of other neuronal events such as neurogenesis in the spinal cord in X. laevis (Schlosser et al. 2002).

Further developmental events occur in E. coqui during the later stages of embryonic development. Operculum development is modified and an ontogenetic reorganization, or condensation, occurs during embryonic development (Callery and Elinson 2000b). This ontogenetic condensation occurs around mid to mid-late 
embryogenesis, TS 10, during which time opercular development, opercular extension and perforation, transpires within a few hours. In metamorphic frogs, opercular development can span weeks or months. Callery and Elinson (2000b) proposed that the period between TS 9 and TS 12 represents a time where the deletion of the tadpole from the ancestral, biphasic lifehistory occurred. During this period of development in the larval olfactory organ, a configuration observed in metamorphic frogs, has been eliminated in E. coqui (Jermakowicz et al. 2004). Interestingly, during this period the serotonergic system undergoes a slow and gradual growth in E. coqui. It is not until after this proposed deleted period that the serotonergic system undergoes rapid maturation similar to the maturation that occurs during metamorphosis.

Acknowledgments We are grateful to the Departmento de Recursos Naturales y Ambientales of Puerto Rico for issuing collecting permits (DRNA: 01-IC-34; 02-IC-067; 03-IC-065) to obtain the adult Coquí for the breeding colony. We would especially like to thank the staff at the El Verde Field Station, Puerto Rico for providing support and use of their facilities, especially Drs. Alonso Ramírez (Director of El Verde Field Station), Jess Zimmerman, Jill Thompson, and Ms. Hilda Hugo. The field station is part of the Long Term Ecological Research project of the Institute for Tropical Ecosystem Studies, University of Puerto Rico, Rio Piedras, funded by the National Science Foundation. Financial support of this research was made possible by the National Science Foundation OSR-9452894 (CHS) and the Office of the Vice President for Research at the University of Michigan (GTE).

\section{References}

Adli DSH, Stuesse AL, Cruce WLR (1999) Immunocytochemistry and spinal projections of the reticular formation in the northern leopard frog, Rana pipiens. J Comp Neurol 404:387-407

Ballion B, Branchereau P, Chapron J, Viala D (2002) Ontogeny of descending serotonergic innervation and evidence for intraspinal 5-HT neurons in the mouse spinal cord. Brain Res Dev Brain Res 137(1):81-88

Bolliet V, Ali MA (1992) Immunohistochemical study of the development of serotoninergic neurons in the brain of the brook trout, Salvelinus fontinalis. Brain Behav Evol 40:234-249

Bolliet V, Perreault S, Ali MA (1994) Development of serotonergic neurons in the brain of the mackerel, Scomber scombrus. An immunohistochemical study. J Fish Biol 44:241-253

Boularand S, Biguet NF, Vidal B, Veron M, Mallet J, Vincent J-D, Dufour S, Vernier P (1998) Tyrosine hydroxylase in the European eel (Anguilla anguilla): cDNA cloning, brain distribution, and phylogenetic analysis. J Neurochem 71:460-470

Buznikov GA, Lambert HW, Lauder JM (2001) Serotonin and serotonin-like substances as regulators of early embryogenesis and morphogenesis. Cell Tissue Res 305:177-186

Callery EM, Elinson RP (2000a) Thyroid hormone-dependent metamorphosis in a direct developing frog. Proc Natl Acad Sci USA 97:2615-2620

Callery EM, Elinson RP (2000b) Operculum development and ontogenetic re-organization in a direct-developing frog. Dev Genes Evol 210:377-381

Callery EM, Fang H, Elinson RP (2001) Frogs without polliwogs: evolution of anuran direct development. BioEssays 23:233-241

Clairambault P, Christophe N, Pairault C, Herbin M, Ward R, Reperant J (1994) Organization of the serotoninergic system in the brain of two amphibian species, Ambystoma mexicanum (Urodela) and Typhlonectes compressicauda (Gymnophiona). Anat Embryol 190(1):87-99
Dahlstrom A, Fuxe K (1964) Evidence for the existence of monoamine-containing neurons in the central nervous system. I. Demonstration of monamines in the cell bodies of brain stem neurons. Acta Physiol Scand 62(Suppl) 232: 1-55

Duellman WE, Trueb L (1986) Biology of amphibians. McGrawHill, New York

Ekström P (1994) Developmental changes in the brain-stem serotonergic nuclei of teleost fish and neural plasticity. Cell Mol Neurobiol 14(4):381-393

Ekström P, van Veen T (1984) Distribution of 5-hydroxytryptamine (serotonin) in the brain of the teleost Gasterosteus aculeatus L. J Comp Neurol 226:307-320

Ekström P, Nyberg L, van Veen T (1985) Ontogenetic development of serotonergic neurons in the brain of a teleost, the threespined stickleback. An immunohistochemical analysis. Brain Res Dev Brain Res 17:209-224

Elinson RP (2001) Direct development: an alternative way to make a frog. Genesis 29:91-95

Frankfurt M, Lauder JM, Azmitia EC (1981) The immunocytochemical localization of serotonergic neurons in the rat hypothalamus. Neurosci Lett 24:227-232

Gilbert LI, Tata JR, Atkinson BG (1996) Metamorphosis: postembryonic reprogramming of gene expression in amphibian and insect cells. Academic, San Diego

Gosner KL (1960) A simplified table for staging anurans embryos and larvae with notes on identification. Herpetol 16:183-190

Hanken J (1999) Larvae in amphibian development and evolution. In: Hall BK, Wake MH (eds) The origin and evolution of larval forms. Academic, San Diego, pp 61-108

Hanken J, Klymkowsky MW, Summers CH, Seufert DW, Ingebrigtsen N (1992) Cranial ontogeny in the direct-developing frog, Eleutherodactylus coqui (Anura: Leptodactylidae), analyzed using whole-mount immunohistochemistry. J Morphol 211:95-118

Hanken J, Carl TF, Richardson MK, Olsson L, Schlosser G, Osabutey CK, Klymkowski MW (2001) Limb development in a "nonmodel" vertebrate, the direct-developing frog Eleutherodactylus coqui. J Exp Zool 291:375-388

Jacobs BL, Azmitia EC (1992) Structure and function of the brain serotonin system. Physiol Rev 72(1):165-215

Janušonis S, Gluncic V,Rakic P (2004) Early Serotonergic Projections to Cajal-Retzius Cells: relevance for cortical development. J Neurosci 24:1652-1659

Jennings DH, Hanken J (1998) Mechanistic basis of life history evolution in anuran amphibians: thyroid gland development in the direct-developing frog, Eleutherodactylus coqui. Gen Comp Endocrinol 111(2):225-32

Jermakowicz III WJ, Dorsey DA, Brown AL, Wojciechowski K, Giscombe CL, Graves BM, Summers CH, Ten Eyck GR (2004) Development of the nasal chemosensory organs in two terrestrial anurans: the directly developing frog, Eleutherodactylus coqui and the metamorphic frog, Bufo americanus. J Morphol 261: 225-248

Kimmel CB, Ballard WW, Kimmel SR, Ullmann B, Schilling TF (1995) Stages of embryonic development of the Zebrafish. Dev Dyn 203:253-310

Kinkead R, Belzile O, Gulemetova R (2002) Serotonergic modulation of respiratory motor output during tadpole development. J Appl Physiol 93:936-946

Lauder JM, Wallace JA, Krebs H, Petrusz P, McCarthy K (1982) In vivo and in vitro development of serotonergic neurons. Brain Res Bull 9:605-625

Lidov HGW, Molliver ME (1982) Immunohistochemical study of the development of serotonergic neurons in the rat CNS. Brain Res Bull 9:559-604

Lowry CA, Plant A, Shanks N, Ingram CD, Lightman SL (2003) Anatomical and functional evidence for a stress-responsive, monoamine-accumulating area in the dorsomedial hypothalamus of adult rat brain. Horm Behav 43:254-262

McLean DL, Fetcho JR (2004) Ontogeny and innervation patterns of dopaminergic, noradrenergic, and serotonergic neurons in larval zebrafish. J Comp Neurol 480:38-56 
van Mier P, Joosten HWJ, van Rheden R, ten Donkelaar HJ (1986) The development of serotonergic raphespinal projections in Xenopus laevis. Int J Dev Neurosci 4(5):465-475

Nakai Y, Ochiai H, Shioda S (1977) Cytological evidence for different types of cerebrospinal fluid-contacting subependymal cells in the preoptic and infundibular recesses of the frog. Cell Tissue Res 176:317-334

Neary T, Northcutt RG (1983) Nuclear organization of bullfrog diencephalon. J Comp Neurol 213:262-278

Nieuwkoop VH, Faber J (1956) Normal Table of Xenopus laevis (Daudin). North-Holland, Amsterdam

Norris DO, Carr JA, Desan PH, Smocks TK, Norman MF (1992) Monoamines and their metabolites in the amphibian (Ambystoma tigrinum) brain: quantitative changes during metamorphosis and captivity. Comp Biochem Physiol 103A(2):279-283

Okado N, Sako H, Homma S, Ishikawa K (1992) Development of serotoninergic system in the brain and spinal cord of the chick. Prog Neurobiol 38(1):93-123

Opdam P, Kemali M, Nieuwenhuys R (1976) Topological analysis of the brain stem of the frogs, Rana esculenta and Rana catesbeiana. J Comp Neurol 165:307-332

Parent A (1973) Distribution of monoamine-containing neurons in the brain stem of the frog, Rana temporaria. J Morphol 139:6778

Parent A, Portras D, Lorraine D (1984) Comparative anatomy of central monoamineric systems. In: Börklund A, Hökfelt T (eds) Handbook of chemical neuroanatomy, vol 2. Classical transmitters in the CNS, Part 1. Elsevier, Amsterdam, pp 409-439

Patel TC, Zhou FC (2005) Ontogeny of 5-HT1A receptor expression in the developing hippocampus. Devel Brain Res 157:4257

Pough FH, Andrews RM, Cadle JE, Crump ML, Savitzky AH, Wells KD (1998) Herpetology. Prentice Hall, Upper Saddle River

Rajaofetra N, Sandillon F, Geffard M, Privat A (1989) Pre- and postnatal ontogeny of serotonergic projections to the rat spinal cord. J Neurosci Res 22:305-321

Roberts A (1988) The early development of neurons in Xenopus embryos revealed by transmitter immunocytochemistry for serotonin, GABA and Glycine. In: Kollos J (ed) Developmental Neurobiology of the Frog. Alan R. Liss Inc., pp 191-205

Sako H, Kojima T, Okado N (1986) Immunohistochemical study on the development of serotonergic neurons in the chick: I. distribution of cell bodies and fibers in the brain. J Comp Neurol 253:61-78

Sano Y, Ueda S, Yamada H, Takeuchi Y, Goto M, Kawata M (1983) Immunohistochemical demonstration of serotonin-containing neurons in the submammalian paraventricular organ. Histochemistry 77:423-430

Scalia F (1976) Structure of the olfactory and accessory olfactory systems. In: Llinas RR, Precht W (eds) Frog Neurobiology: A Handbook. Springer Berlin Heidelberg, New York, pp 213-233

Schlosser G (2003) Mosaic evolution of neural development in anurans: acceleration of spinal cord development in the direct developing frog Eleutherodactylus coqui. Anat Embryol 206:215-227

Schlosser G, Roth G (1997a) Development of the retinal is altered in the directly developing frog Eleutherodactylus coqui (Leptodactylidae). Neurosci Lett 224(3):153-156

Schlosser G, Roth G (1997b) Evolution of nerve development in frogs: II. Modified development of the peripheral nervous system in the direct-developing frog, Eleutherodactylus coqui (Leptodactylidae). Brain Behav Evol 50:94-128

Schlossser G, Kintner C, Northcutt RG (1999) Loss of ectodermal competence for lateral line placode formation in the direct developing frog Eleutherodactylus coqui. Dev Biol 213:354-369
Schlossser G, Koyano-Nakagawa N, Kintner C (2002) Thyroid hormone promotes neurogenesis in the Xenopus spinal cord. Dev Dyn 225:485-498

Shi Y-B (1996) Thyroid hormone-regulated early and late genes during amphibian metamorphosis. In: Gilbert LI, Tata JR, Atkinson BG (eds) Metamorphosis: post-embryonic reprogramming of gene expression in amphibian and insect cells. Academic, San Diego, pp 505-533

Sillar KT, Reith CA, McDearmid JR (2002) Development and aminergic neuromodulation of a spinal locomotor network controlling swimming in Xenopus larvae. Ann N Y Acad Sci 860:318-332

Smeets WJAJ, González A (1990) Are putative dopamine-accumulating cell bodies in the hypothalamic periventricular organ a primitive brain character of nonmammalian vertebrates? Neurosci Lett 114:248-252

Smeets WJAJ, González A (2000) Catecholamine systems in the brain of vertebrates: new perspectives through a comparative approach. Brain Res Rev 33:308-379

Smeets WJAJ, Steinbusch HWM (1990) New insights into the reptilian catecholaminergic systems as revealed by antibodies against the neurotransmitters and their synthetic enzymes. J Chem Neuroanat 3:25-43

Smeets WJAJ, Kidjan M, Jonker AJ (1991) $\alpha$-MPT does not affect dopamine levels in the periventricular organ of lizards. Neuroreport 2:369-372

Summers TR, Summers CH, Desan PH, Smock TK (1991) Activation of the serotonergic system in chick spinal cord during hatching. J Exp Zool 257:330-335

Takeda N (1997) The metabolism of biogenic monoamines during embryogenesis and metamorphosis in two anuran species. Gen Comp Endo 106:361-373

Tata JR (1996) Hormonal interplay and thyroid hormone receptor expression during amphibian metamorphosis. In: Gilbert LI, Tata JR, Atkinson BG (eds) Metamorphosis: postembryonic reprogramming of gene expression in amphibian and insect cells. Academic, San Diego, pp 466-503

Ten Eyck GR, Ronan PJ, Renner KJ, Summers CH (2005) Serotonin metabolism in directly developing frog embryos during paternal care. Neurosci Lett 388:100-105

Terlou M, van Straaten HWM, van Oordt PGWJ (1972) The development of hypothalamic monoaminergic neurons in Xenopus laevis tadpoles in relation to background-dependent colour change. Int J Dev Neurosci 4(5):465-475

Townsend DS, Steward MM (1985) Direct development in Eleutherodactylus coqui (Anura: Leptodactylidae): a staging table. Copeia 1985(2):423-436

Ueda S, Nojyo Y, Sano Y (1984) Immunohistochemical demonstration of the serotonin neuron system in the central nervous system of the bullfrog, Rana catesbeiana. J Comp Neurol 169:219-229

Verney C (2003) Phenotypic expression of monoamines and GABA in the earlier development of the human telencephalon, transient or not transient. J Chem Neuroanat 26:283-292

Wallace JA (1985) An immunocytochemical study of the development of central serotonergic neurons in the chick embryo. J Comp Neurol 236:443-453

Wallace JA, Lauder JM (1983) Development of the serotonergic system in the rat embryo: an immunocytochemical study. Brain Res Bull 10:459-479

Woolston A-M, Wedderburn JFS, Sillar KT (1994) Descending serotonergic spinal projections and modulation of locomtor rhythmicity in Rana temporaria embryos. Proc R Soc Lond B Biol Sci 255:73-79

Zug GR (1993) Herpetology: an introductory biology of amphibians and reptiles. Academic, San Diego 